\title{
PERINATAL OUTCOME OF TWIN REVERSED ARTERIAL PERFUSION SEQUENCE: A SINGLE CENTER'S EXPERIENCE
}

\author{
Mi-Young Lee, MD, Hye-Sung Won, MD, Kyung A Lee, MD, Kyu-Sang Kyeong, MD, Eun-Jin Jeon, MD, \\ Jae-Yoon Shim, MD, Pil-Ryang Lee, MD, Ahm Kim, MD \\ Department of Obstetrics and Gynecology, Asan Medical Center, University of Ulsan College of Medicine, Seoul, Korea
}

\section{Objective}

To report our experience of using radiofrequency ablation (RFA) to treat fetuses diagnosed with twin reversed arterial perfusion (TRAP) sequence and to evaluate the perinatal outcome of pump twins.

\section{Methods}

Twenty-six fetuses diagnosed with the TRAP sequence were retrospectively analyzed between July 1998 and September 2011 at Asan Medical Center. Four were lost to follow-up after diagnosis and, therefore, were excluded from further evaluation. The perinatal outcomes of pump twins were evaluated by reviewing the medical records.

\section{Results}

Twenty-two fetuses were diagnosed with the TRAP sequence during the study period, including 15 monochorionic-diamniotic pregnancies and four monochorionic-monoamniotic pregnancies. Three patients had triplet pregnancies. The median gestational age at diagnosis was 17.4 weeks (range, 11.0 to 27.0 weeks). Of these 22 cases, in utero RFA was performed in 11 (50\%), alcohol ablation in one $(4.5 \%)$ and the remaining $10(45.5 \%)$ underwent conservative management. The median gestational age at in utero intervention was 21.0 weeks (range, 17.6 to 25.0 weeks). The overall neonatal survival rate was $77 \%$ (17 of 22). The median gestational age at delivery was 37.3 weeks (range, 30.2 to 40.1 weeks). All of the surviving infants are doing well without any complications.

\section{Conclusion}

For fetuses with the TRAP sequence, proper in utero treatment with RFA enables to continue the pregnancy with a good prognosis.

Keywords: Twin reversed arterial perfusion sequence; Acardiac twin; Radiofrequency ablation; Fetal therapy

The twin reversed arterial perfusion (TRAP) sequence, also known as acardiac twinning, is a unique complication of monochorionic twin pregnancies that occurs in approximately one of 35,000 pregnancies and $1 \%$ of monozygotic twins [1]. The acardiac twin receives all of its blood from the pump twin through artery-toartery anastomosis, resulting in a retrograde flow of deoxygenated blood into the acardiac twin through the umbilical artery [2]. This results in poor or absent development of the heart and upper body in the acardiac twin and an increased risk of high-output cardiac failure, polyhydramnios, and the consequential death of the structurally normal pump twin [3].

Because of the high risk of perinatal death to the pump twin and polyhydramnios-related preterm delivery, an intervention to interrupt the blood flow to the acardiac twin is usually performed. A variety of minimally invasive treatment modalities, such as cord ligation, laser coagulation, interstitial laser therapy, and radiofre-

Received: 2012.3.13. Revised: 2012.5.2. Accepted: 2012.5.4. Corresponding author: Hye-Sung Won, MD

Department of Obstetrics and Gynecology, Asan Medical Center, University of Ulsan College of Medicine, 88 Olympic-ro 43-gil, Songpa-gu, Seoul 138-736, Korea Tel: +82-2-3010-3644 Fax: +82-2-3010-6944

E-mail: hswon@amc.seoul.kr

This is an Open Access article distributed under the terms of the Creative Commons Attribution Non-Commercial License (http://creativecommons.org/licenses/ by-nc/3.0/) which permits unrestricted non-commercial use, distribution, and reproduction in any medium, provided the original work is properly cited.

Copyright (C) 2012. Korean Society of Obstetrics and Gynecology 
quency ablation (RFA), are widely used to achieve this [4-7]. In a previous systemic review of these treatment modalities, it was concluded that intrafetal ablation is the treatment of choice because it is simpler, safer, and more effective than cord occlusion [8]. There are only few case reports regarding the in utero intervention of the TRAP sequence in Korea. Thus, the aim of our study was to report our experiences of using RFA to treat fetuses with the TRAP sequence and to evaluate the perinatal outcomes of pump twins.

\section{Materials and Methods}

Following institutional review board approval, we retrospectively analyzed 26 pregnancies that were complicated by the TRAP sequence between July 1998 and September 2011 at Asan Medical Center, Seoul, Korea. Four pregnancies were lost after diagnosis of the TRAP sequence and, therefore, were excluded from further
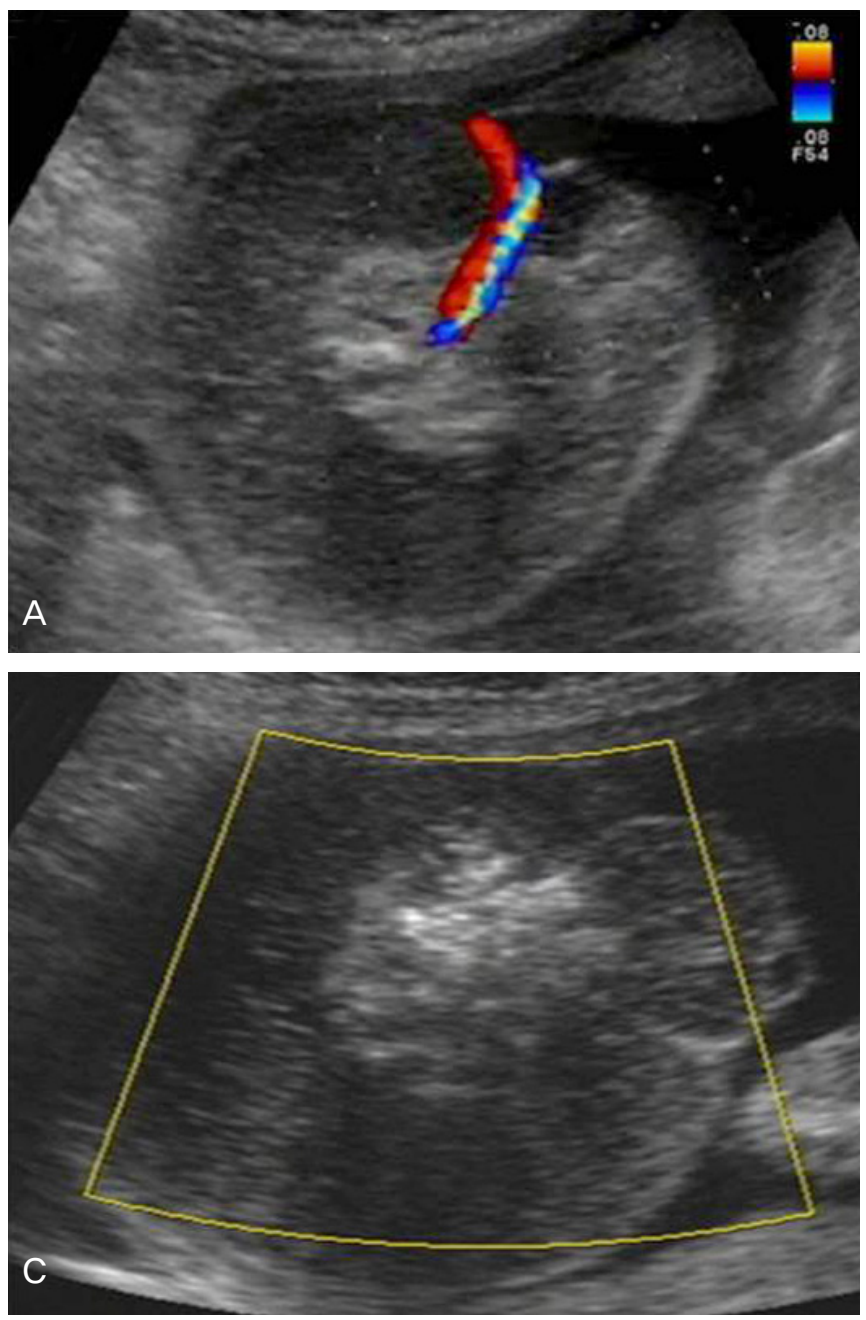

evaluation. All patients received a detailed high-resolution ultrasound, including color Doppler. The size of the acardiac twin was assessed by measuring the femur length of the acardiac twin, except in four cases where there was no identifiable femur. The presence of polyhydramnios, or fetal hydrops, and other associated anomalies in the pump twin were also evaluated. Indications for in utero RFA included an initially large femur size in the acardiac twin compared with the pump twin, which appeared as a size discrepancy of about 2 weeks, or a continuously growing femur in the acardiac twin with the presence of vascularity within the umbilical cord and/or associated polyhydramnios. The perinatal outcomes of the pump twins were evaluated by reviewing the medical records.

\section{RFA technique}

RFA was performed under local anesthesia. Using real-time ultrasound guidance, a 17-gauge RFA needle with 2-cm tines (Boston

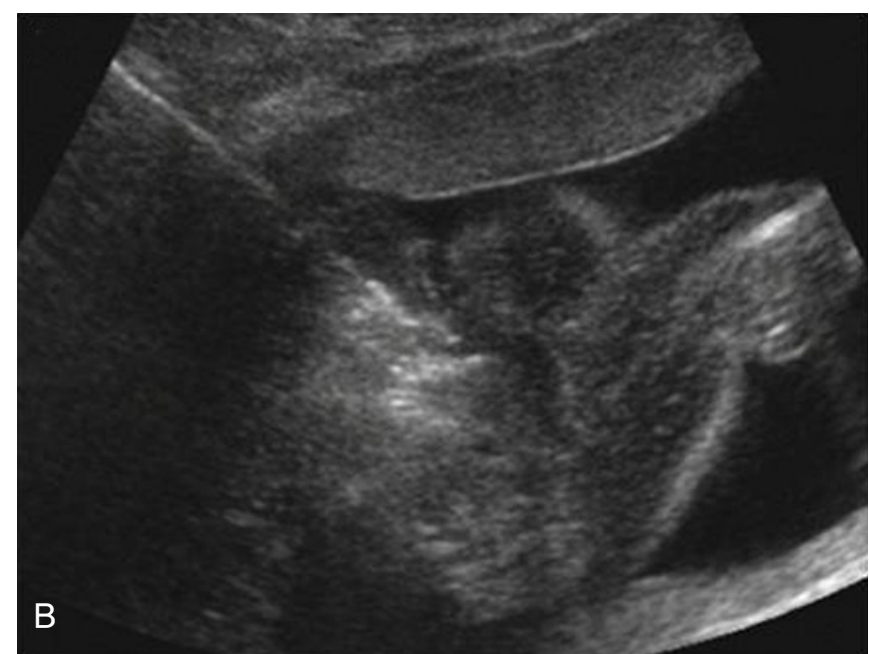

Fig. 1. Radiofrequency ablation (RFA) technique. (A) The RFA needle must be inserted at the level of umbilical cord insertion, which can be easily detected using color Doppler. Ultrasonographic finding demonstrates a single umbilical artery. (B) During RFA, the effects of ablation can be seen by observing the echogenic area around the ablation site. (C) After successful ablation, the cessation of blood flow can be confirmed by color Doppler. 
Scientific, Boston, MA, USA) was inserted through the maternal abdominal wall into the fetal abdomen at the level of umbilical cord insertion (Fig. 1A). RFA was started with $10 \mathrm{~W}$ of power for 30 seconds, and then the power was increased by $5 \mathrm{~W}$ every 30 seconds (Fig. 1B). The procedure was stopped when the cessation of blood flow to the acardiac twin was confirmed by color Doppler (Fig. 1C). Prophylactic tocolysis with intravenous magnesium sulfate or ritodrine and antibiotics were administered, as a routine protocol, before and after the procedure. An ultrasound examination was performed to assess the pump twin on postoperative day 1 .

\section{Results}

Over the course of the study period, 22 fetuses were diagnosed with the TRAP sequence. Fifteen of the pregnancies were monochorionic-diamniotic pregnancies and four were monochorionicmonoamniotic. Three patients had triplet pregnancies. The median gestational age at diagnosis was 17.4 weeks (range, 11.0 to 27.0 weeks). Three cases were associated with polyhydramnios and one case demonstrated cardiomegaly with associated polyhydramnios in the pump twin, but none developed fetal hydrops. Two cases were diagnosed with associated anomalies but had a normal karyotype. Two fetuses had only one umbilical artery, and one of these also presented with congenital heart defects; specifically, right aortic arch and bilateral superior vena cava.

Of these 22 cases, in utero RFA was performed in 11 cases (50\%), alcohol ablation was performed in one case (4.5\%), and the remaining 10 cases (45.5\%) received conservative management. The outcomes of the in utero interventions are listed in Table 1. The median gestational age at the time of the in utero interventions was 21.0 weeks (range, 17.6 to 25.0 weeks). All cases associated with polyhydramnios underwent in utero intervention (three RFA and one alcohol ablation). In case 10, although the discrepancy between the femur lengths of the pump twin and acardiac twin was 4.4 weeks, the femur had became longer by the time of the follow up ultrasound examination, and RFA was therefore performed. All of the pump twins survived immediately after RFA, however three fetuses died at least 3 weeks after receiving RFA. Two cases of intrauterine fetal death occurred because of

Table 1. Outcomes of in utero intervention

\begin{tabular}{|c|c|c|c|c|c|c|c|c|c|c|}
\hline Case & Intervention & Chorionicity & $\begin{array}{c}\text { GA at } \\
\text { diagnosis } \\
\text { (wk) }\end{array}$ & $\begin{array}{c}\text { FL (mm)/ } \\
\text { discrepancy } \\
\text { (wk) }\end{array}$ & $\begin{array}{c}\text { Polyhydramnios/ } \\
\text { fetal hydroops/ } \\
\text { cardiomegaly }\end{array}$ & $\begin{array}{c}\text { GA at } \\
\text { intervention } \\
\text { (wk) }\end{array}$ & $\begin{array}{c}\text { GA at } \\
\text { delivery } \\
\text { (wk) }\end{array}$ & $\begin{array}{l}\text { Reason } \\
\text { for PTB }\end{array}$ & $\begin{array}{l}\text { Birth } \\
\text { weight } \\
\text { (g) }\end{array}$ & Outcome \\
\hline 1 & RFA & MCMA & 21.3 & $31 / 0.5$ & Yes/No/Yes & 22.3 & 26.6 & $\begin{array}{l}\text { Cord } \\
\text { stricture }\end{array}$ & & FDIU \\
\hline 2 & RFA & MCDA & 13.1 & $18 / 1$ & No/No/No & 19.5 & 37.0 & & c & Alive \\
\hline 3 & RFA & MCMA & 16.6 & 23.3/1.4 & Yes/No/No & 20.6 & 39.0 & & 3,240 & Alive \\
\hline 4 & RFA & MCMA & 16.5 & $22.5 / 1.3$ & No/No/No & 20.4 & 34.6 & IUGR & 1,350 & Alive \\
\hline 5 & RFA & MCDA & 20.1 & $28.2 / 1.4$ & No/No/No & 20.1 & 23.4 & PTL & & Died \\
\hline 6 & RFA & MCDA & 13.5 & $17.9 / 1.4$ & No/No/No & 17.6 & 21.4 & $\begin{array}{l}\text { Cord } \\
\text { stricture }\end{array}$ & & FDIU \\
\hline 7 & RFA & MCDA & 21.1 & $27 / 2$ & No/No/No & 21.1 & 37.2 & & 2,980 & Alive \\
\hline 8 & RFA & MCDA & 22.5 & $32 / 1.3$ & No/No/No & 22.6 & 38.6 & & 3,125 & Alive \\
\hline 9 & RFA & MCDA & 24.6 & $39.7 / 2$ & No/No/No & 25 & 39.6 & & 2,870 & Alive \\
\hline 10 & RFA & $\begin{array}{c}\text { Triplet } \\
\text { (DCTA) }\end{array}$ & 17.3 & $13 / 4.4$ & No/No/No & 19.3 & 33.6 & PPROM & $\begin{array}{l}1,980 \\
1,780\end{array}$ & Alive \\
\hline 11 & RFA & $\begin{array}{c}\text { Triplet } \\
\text { (MCDA) }\end{array}$ & 21.0 & $33 / 0.4$ & Yes/No/No & 25 & 30.2 & PPROM & $\begin{array}{r}980 \\
1,170\end{array}$ & Alive \\
\hline 12 & $\begin{array}{l}\text { Alcohol } \\
\text { ablation }\end{array}$ & MCMA & 23.3 & b & Yes/No/No & 23.6 & 23.6 & & & FDIU \\
\hline
\end{tabular}

GA, gestational age; FL, femur length; PTB, preterm birth; RFA, radiofrequency ablation; MCMA, morochorionic-monoamniotic; FDIU, fetal death in utero; MCDA, monochorionic-diamniotic, IUGR, intrauterine growth retardation; PTL, preterm labor; DCTA, dichorionic-triamriotic; PPROM, preterm premature rupture of membranes.

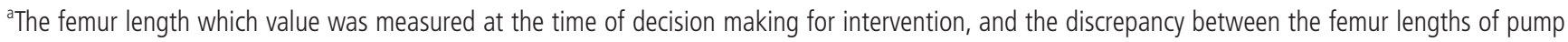
twin and acardiac twin are demonstrated; ${ }^{b}$ There was no identifiable femur; ${ }^{\circ}$ No exact birth weight was available, because the baby was delivered at the private clinic. 
Table 2. Outcomes of conservative management

\begin{tabular}{|c|c|c|c|c|c|c|c|c|}
\hline Case & Chorionicity & $\begin{array}{c}\text { GA at } \\
\text { diagnosis } \\
\text { (wk) }\end{array}$ & $\begin{array}{l}\text { Growing } \\
\text { femur }^{\mathrm{a}}\end{array}$ & $\begin{array}{l}\text { Polyhydramnios/ } \\
\text { fetal hydroops/ } \\
\text { cardiomegaly }\end{array}$ & $\begin{array}{l}\text { GA at } \\
\text { delivery } \\
\text { (wk) }\end{array}$ & $\begin{array}{l}\text { Reason } \\
\text { for PTB }\end{array}$ & $\begin{array}{l}\text { Birth weight } \\
\text { (g) }\end{array}$ & Outcome \\
\hline 1 & MCDA & 25.3 & No & No/No/No & 36.4 & PTL & 2,300 & Alive \\
\hline 2 & MCDA & 16.6 & No & No/No/No & 39.2 & & 3,400 & Alive \\
\hline 3 & MCDA & 11.4 & No & No/No/No & 39.4 & & 3,115 & Alive \\
\hline 4 & MCDA & 16.5 & No & No/No/No & 40.1 & & 2,885 & Alive \\
\hline 5 & MCDA & 23.1 & No & No/No/No & 35.2 & IUGR & 1,930 & Alive \\
\hline 6 & MCDA & 17.4 & No & No/No/No & 39.6 & & 3,360 & Alive \\
\hline 7 & MCDA & 11.0 & No & No/No/No & 13 & & & FDIU \\
\hline 8 & MCDA & 14.0 & No & No/No/No & 37.1 & & 2,950 & Alive \\
\hline 9 & MCDA & 16.2 & No & No/No/No & 37.6 & & 2,400 & Alive \\
\hline 10 & $\begin{array}{l}\text { Triplet } \\
\text { (DCDA) }\end{array}$ & 27.0 & No & No/No/No & 35 & PTL & $\begin{array}{l}1,866 \\
2,124\end{array}$ & Alive \\
\hline
\end{tabular}

GA, gestational age; PTB, preterm birth; MCDA, monochorionic-diamniotic, PTL, preterm labor; IUGR, intrauterine growth retardation; FDIU, fetal death in utero; DCDA, dichorionic-diamniotic.

${ }^{a}$ Continuous growth of the femur compared to the initial measurement.

cord stricture at 26.6 weeks and 21.4 weeks of gestation, occurring 4.3 and 3.5 weeks after RFA, respectively (cases 1 and 6). In another case, a bulging amniotic membrane occurred after RFA and, despite emergency cerclage, the fetus was delivered without viability at 23.4 weeks of gestation (case 5). Before the introduction of RFA at our center, there was one case of alcohol ablation in a monoamniotic acardiac twin (case 12). Ultrasonographic findings at 23.3 weeks demonstrated severe hydropic changes in the acardiac twin and polyhydramnios in the pump twin. Under continuous ultrasound guidance, $2.5 \mathrm{~mL}$ of absolute alcohol was injected into the umbilical artery of the acardiac twin using the 22-gauge spinal needle. Immediately after alcohol injection, the pump twin demonstrated bradycardia and subsequently died after 30 minutes. Of the 11 fetuses who received RFA, six (55\%) were delivered before 37 weeks of gestation. The reasons for these preterm deliveries included preterm premature rupture of the membrane (PPROM; cases 10 and 11, both survived), preterm labor (case 5, resulted in death), cord accident (cases 1 and 6, neither survived) and intrauterine growth retardation (case 4, survived). Table 2 demonstrates the outcomes of fetuses with the conservative management. The acardiac twins with an initially small femur compared with the pump twin, a discrepancy of greater than 3 weeks, no change or decline in femur length and/or cessation of blood flow in consecutive scans were observed carefully without interventions. Neither fetuses in these cases showed femur growth compared with the initial measurement nor were associated with polyhydramnios or cardiomegaly. One case resulted in the death of the fetus in early gestation. Three fetuses were preterm deliveries due to preterm labor and intrauterine growth retardation (cases 1 , 5 , and 10).

The overall neonatal survival rate was $77 \%$ (17 of 22 fetuses). The median gestational age at delivery was 37.3 weeks (range, 30.2 to 40.1 weeks) and there was no significant difference in gestational age at delivery between in utero intervention and conservative management group $(P=0.277)$. Three women with triplet pregnancies delivered at 33.6, 30.2, and 35 weeks of gestation, respectively. All of the surviving infants are doing well without complications.

\section{Discussion}

The mortality rate of the pump twin has been reported as greater than $50 \%$ because of complications due to congestive heart failure, polyhydramnios, cord entanglement, and preterm labor [2,3]. With proper in utero treatment, the normal (or pump twin) can survive with a good clinical outcome. Our study shows that 8 of the 11 pump twins who were treated with RFA (73\%) survived without complications. Although this survival rate is lower in comparison with other studies, which are $92 \%, 86 \%, 94 \%, 100 \%$, respectively [7,9-11], our results are worthwhile as the first and largest series performed in Korea. There are only 2 other case reports in Korea on the successful use of in utero intervention to manage the TRAP sequence. In 2004, Lee et al. [12] reported the 
use of intra-abdominal alcohol ablation. Another case, which was treated using RFA, was reported by Jang et al. [13] in 2010.

The use of intrafetal RFA to treat the TRAP sequence, which is the most recently reported technique, was first reported in 2002 [9]. The authors concluded that RFA can effectively obliterate the blood supply to the acardiac twin. At that time, they used a 3-mm, 14-gauge RFA needle, and 3 of 13 infants (23\%) were delivered preterm because of PPROM. Although from this result, Tan and Sepulveda [8] suggested the possibility that membrane ruptures and preterm delivery are associated with the use of the larger devices than other modalities (e.g., alcohol ablation, monopolar diathermy, and interstitial laser), the morbidity related to RFA was not accepted as the only series reported at that time. Since then, 3 more series have been published on the efficacy of RFA $[7,10,11]$. Lee et al. [7] reported an update to their initial experiences. They used a 17-gauge needle, which is approximately $1.3 \mathrm{~mm}$ in diameter, to treat 6 cases. The second series by Livingston et al. [10] demonstrated that using a 19-gauge needle resulted in only 1 of 13 cases (8\%) that were treated with RFA to be delivered in less than 32 weeks due to PPROM. Although no details regarding preterm delivery were noted in the latest series, the authors reported a 100\% survival rate for their 7 RFA cases [11]. Along with the development of these instruments, RFA has become known as a safe and effective treatment modality.

This study includes four monochorionic-monoamniotic pregnancies that all underwent in utero intervention (three RFA and one alcohol ablation). Intrauterine fetal death occurred in one case that was treated with RFA and alcohol ablation, respectively. An amniotic band caused cord stricture and the subsequent death of the pump twin after RFA. Among those that survived, RFA were performed at 20.6 and 20.4 weeks of gestation and two infants were delivered at 39 and 34.6 weeks of gestation, respectively. So far, there are no reports on the successful use of RFA to treat a monoamniotic acardiac twin. Despite the relatively high mortality rate of monoamniotic twins, mainly because of cord entanglement, here we report two cases with good clinical outcomes. This result could be very useful for counseling parents about the effects of intervention for treating monoamniotic twins who already at high risk.

At our institution, intervention was determined by measuring the femur length, instead of the weight of the acardiac twin, which is the limitation of our study. We measured only the femur length, and when it was large enough in size to those of the pump twin or gradually increased with serial scans, intervention was performed. The femur is easily detected by ultrasound in the acardius acephalus, which is the most common form of the acardiac twin and may grow in proportion to whole body mass. Thus the growth of acardiac twins can be assessed by measuring the femur length. However, the femur does not reflect the whole body in cases of acardius acormus or acardius amorphous, in which case no definite femur is present. The weight of the acardiac twin can be determined by several methods. Moore et al. [3] described the formula for measuring the weight of the acardiac twin (weight $[\mathrm{g}]=1.21 \times(\text { longest dimension }[\mathrm{cm}])^{2}(1.66 \times$ longest dimension $[\mathrm{cm}])$, and when the acardiac twin: pump twin ratio is greater than $70 \%$, the incidence of preterm delivery, polyhydramnios, and congestive heart failure increases [3]. However their reports were based on postmortem measurements and provide limited applications to prenatal diagnosis. Wong and Sepulveda [14] proposed a new classification system based on abdominal circumference (AC), and they suggested that prompt intervention is necessary when the $\mathrm{AC}$ ratio between the acardiac and pump twin is greater than or equal to $50 \%$ [14]. The estimated fetal weight can also be calculated by measuring the acardiac twin in three dimensions (longitudinal, anterior-posterior, and transverse). Some authors concluded that conservative management with close monitoring may be safe when the weight ratio between the acardiac and pump twin is less than $50 \%$ [11]. However, nothing has been identified as the most accurate method for evaluating acardiac twins. Therefore, in order to maximize perinatal outcomes, standardized assessments are needed.

In our series, none of the pump twins developed fetal hydrops, indicating that the serial antenatal surveillance for determining the optimal timing for intervention is important. However, there is still no consensus regarding the appropriate follow-up interval and timing of intervention. Our recommendation is that when a diagnosis is made, patients should be followed up weekly and if any important signs are present (e.g., increase in the size of the acardiac twin, fetal hydrops, congestive heart failure, polyhydramnios, etc.), then prompt management is warranted. Intervention is best performed after 16 weeks of gestation because an earlier intervention carries technical difficulties and a higher risk of miscarriage, but prior to 20 weeks because interventions later than this are associated with a higher incidence of obstetrical complications.

RFA is a minimally invasive, effective technique for treatment of the TRAP sequence and allows the continuation of the pregnancy with a good clinical prognosis. 


\section{KOREAN JOURNAL OF OBSTETRICS \& GYNECOLOGY}

Mi-Young Lee, et al. Perinatal outcome of TRAP sequence

\section{References}

1. James WH. A note on the epidemiology of acardiac monsters. Teratology 1977;16:211-6.

2. Van Allen MI, Smith DW, Shepard TH. Twin reversed arterial perfusion (TRAP) sequence: a study of 14 twin pregnancies with acardius. Semin Perinatol 1983;7:285-93.

3. Moore TR, Gale S, Benirschke K. Perinatal outcome of fortynine pregnancies complicated by acardiac twinning. Am J Obstet Gynecol 1990;163:907-12.

4. Quintero RA, Chmait RH, Murakoshi T, Pankrac Z, Swiatkowska M, Bornick PW, et al. Surgical management of twin reversed arterial perfusion sequence. Am J Obstet Gynecol 2006;194:982-91.

5. Hecher K, Lewi L, Gratacos E, Huber A, Ville Y, Deprest J. Twin reversed arterial perfusion: fetoscopic laser coagulation of placental anastomoses or the umbilical cord. Ultrasound Obstet Gynecol 2006;28:688-91.

6. Scheier M, Molina FS. Outcome of twin reversed arterial perfusion sequence following treatment with interstitial laser: a retrospective study. Fetal Diagn Ther 2012;31:35-41.

7. Lee $H$, Wagner AJ, Sy E, Ball R, Feldstein VA, Goldstein RB, et al. Efficacy of radiofrequency ablation for twin-reversed arterial perfusion sequence. Am J Obstet Gynecol 2007;196:459. e1-4.

8. Tan TY, Sepulveda W. Acardiac twin: a systematic review of minimally invasive treatment modalities. Ultrasound Obstet Gynecol 2003;22:409-19.

9. Tsao K, Feldstein VA, Albanese CT, Sandberg PL, Lee H, Harrison MR, et al. Selective reduction of acardiac twin by radiofrequency ablation. Am J Obstet Gynecol 2002;187:635-40.

10. Livingston JC, Lim FY, Polzin W, Mason J, Crombleholme TM. Intrafetal radiofrequency ablation for twin reversed arterial perfusion (TRAP): a single-center experience. Am J Obstet Gynecol 2007;197:399.e1-3.

11. Jelin E, Hirose $S$, Rand L, Curran P, Feldstein V, GuevaraGallardo $S$, et al. Perinatal outcome of conservative management versus fetal intervention for twin reversed arterial perfusion sequence with a small acardiac twin. Fetal Diagn Ther 2010;27:138-41.

12. Lee SW, Lee SO, Park MH, Kim YJ, Chun SH, Ahn JJ, et al. Successful management with intra-abdominal alcohol ablation of acardiac twin and amniodrainage in twin reversed arterial perfusion sequence with severepolyhydramnios. Korean J Obstet Gynecol 2004;47:1394-9.

13. Jang JH, Moon MJ, Park HR, Ahn EH, Jung SH, Lee YM, et al. Case reports A case of acardiac twin pregnancy with fetus survival after successful radiofrequency ablation of umbilical cord. Korean J Obstet Gynecol 2010;53:449-54.

14. Wong AE, Sepulveda W. Acardiac anomaly: current issues in prenatal assessment and treatment. Prenat Diagn 2005;25:796-806. 


\section{역동맥관류 연쇄의 주산기 예후: 단일기관 경험}

\section{울산대학교 의과대학 서울아산병원 산부인과학교실}

이미영, 원혜성, 이경아, 경규상, 전은진, 심재윤, 이필량, 김 암

\section{목적}

고주파 융해술을 이용하여 무심장 쌍둥이를 치료한 경험과 정상 펌프 태아의 주산기 예후를 보고하고자 하였다.

\section{연구방법}

1998년 7월부터 1011년 9월까지 역동맥관류 연쇄로 진단된 26예를 대상으로 후향적 연구를 시행하였다. 그중, 진단 후 추적 관찰이 불 가능했던 4예를 제외하였다. 정상 펌프 태아의 주산기 예후는 의무기록을 이용하여 조사하였다.

\section{결과}

총 22명의 무심장 쌍둥이 중, 단일융모막두양막성 쌍태임신이 15예, 단일융모막단일양막성 쌍태임신이 4예, 삼태아 임신이 3예 진단되었 다. 진단 당시 주수의 중앙값은 17.4주(범위, 11-27주)였다. 11예에서 고주파융해술을, 1 예에서 알코올절제술을, 10예에서는 보존적 치료 를 시행하였다. 자궁내 시술 당시 주수의 중앙값은 21주(범위, 17.6-25주)였고, 분만 당시 주수의 중앙값은 37.3주(범위, 30.2-40.1주)였 다. 신생아 생존율은 $77 \%(17 / 22)$ 였다.

\section{결론}

본 연구 결과, 고주파융해술을 이용하여 무심장 쌍둥이를 치료함으로써 정상 펌프 태아의 예후를 향상시킬 수 있을 것으로 생각된다.

중심단어: 역동맥관류 연쇄, 무심장 쌍둥이, 고주파융해술, 태아 치료 